\title{
Kekuatan Yuridis Akta Konsen Roya Yang Dibuat Oleh Notaris Sebagai Syarat Pencoretan Hak Tanggungan
}

\section{Putu Silkyamara Nandha Rossana1, Dewa Gede Pradnya Yustiawan²}

1Fakultas Hukum Universitas Udayana, E-mail: psnrossana16@gmail.com

2Fakultas Hukum Universitas Udayana, E-mail: pradnya_yustiawan@unud.ac.id

Info Artikel
Masuk: 17 Januari 2021
Diterima : 23 Januari 2021
Terbit : 1 April 2021
Keywords :
Juridicial power; The deed of
consent roya; The mortgage
right

Kata kunci:
Kekuatan yuridis; Akta konsen
roya; Hak tanggungan
Corresponding Author:
Putu Silkyamara Nandha
Rossana, E-mail:
psnrossana16@gmail.com
DOI :
10.24843/AC.2021.v06.i01.p10

\begin{abstract}
This study aims to find out and anayze the capacity and the juridical power the deed of consent roya made by a notary as a condition for withdrawal of mortgage rights. This study uses normative legal research with approached by statue and conceptual approach. Based on the findings, it is known the deed of consent roya is a notarial deed which has a functions as a substituted for the lost mortgage certificate, functions as a condition for the write-off ot the mortgage rights. As for the juridicial power of the deed of consent roya can be seen from the perspective of legal certainty where the notary act a role in making the deed to fulfil roya process as the National Land Office and can be a concrete proof that the debt has been paid off and has been written off.

\begin{tabular}{l} 
Abstrak \\
\hline Tulisan ini bertujuan untuk mengetahui dan menganalisis \\
mengenai kapasitas serta kekuatan yuridis akta konsen roya \\
yang dibuat oleh notaris sebagai syarat pencoretan hak \\
tanggungan. Studi ini menggunakan metode penelitian hukum \\
normatif dengan menggunakan pendekatan perundang- \\
undangan dan pendekatan konseptual. Berdasarkan hasil \\
temuan, diketahui bahwa akta konsen roya merupakan akta \\
notariil yang memiliki kapasitas sebagai pengganti sertifikat hak \\
tanggungan yang hilang, yang berguna sebagai syarat \\
pencoretan hak tanggungan. Adapun mengenai kekuatan yuridis \\
akta konsen roya dapat dilihat dari perspektif kepastian hukum \\
yang mana notaris berperan dalam pembuatan akta tersebut \\
guna memenuhi proses roya di Kantor Pertanahan Nasional dan \\
dapat dijadikan alat pembuktian yang konkrit bahwa utang \\
sudah lunas dan telah dihapuskan.
\end{tabular}
\end{abstract}

\section{Pendahuluan}

Sebagai pejabat umum seorang notaris memiliki wewenang, sebagaimana Pasal 15 ayat (1) Undang-Undang Nomor 2 Tahun 2014 tentang Perubahan Atas Undang-Undang Nomor 30 Tahun 2004 tentang Jabatan Notaris (selanjutnya disebut UUJN/P) menyatakan "notaris berwenang membuat akta autentik mengenai semua perbuatan, perjanjian, dan penetapan yang diharuskan oleh peraturan perundang-undangan dan/atau yang dikehendaki oleh yang berkepentingan untuk dinyatakan dalam akta 
autentik, menjamin kepastian tanggal, membuat akta, menyimpan akta, memberikan grosse, salinan dan kutipan akta, semuanya itu sepanjang pembuatan akta itu tidak juga ditugaskan atau dikecualikan kepada pejabat lain atau orang lain yang ditetapkan oleh undang-undang."

Apabila terdapat permasalahan hukum akta autentik dapat digunakan sebagai alat pembuktian yang terkuat sebab pembuatannya undang-undang yang menentukan. Sementara itu, akta autentik tersebut yang mana para pihak dapat menggunakannya sebagai alat bukti. Pada umumnya, terdapat 3 (tiga) kekuatan pembuktian yang terdapat dalam akta autentik yakni lahiriah, formil, dan material. ${ }^{1}$ Pertama, kekuatan pembuktian lahiriah ialah akta autentik dapat membuktikan keabsahan bahwa lahir sesuai aturan hukum yang ada. Kedua, kekuatan pembuktian formil ialah akta autentik yang dapat memberikan kepastian bahwa fakta yang terdapat dalam akta memang benar adanya. Serta ketiga, kekuatan pembuktian material ialah akta autentik tentang kebenaran materi suatu akta. ${ }^{2}$

Seorang notaris dapat dibebani tanggungjawab atas perbuatannya pada saat menjalankan tugas dan wewenangnya dalam pembuatan akta autentik. Sebagaimana termuat pada Pasal 1 angka 1 UUJN/P, tanggungjawab ialah suatu bentuk kesediaan untuk melaksanakan kewajibannya. Kebenaran materil merupakan bentuk tanggungjawab notaris atas akta yang dibuatnya. Terdapat pembatasan pertanggungjawaban seorang notaris yang mana notaris hanya bertanggungjawab secara formal sesuai peraturan hukum, bukan bertanggungjawab atas kelalaian ataupun kesalahan atas isi akta yang dibuat dihadapannya. Peran akta autentik di masyarakat sangatlah penting khususnya di lingkungan perbankan yang kewenangannya yaitu membuat perjanjian kredit.

Untuk melangsungkan penyerahan kredit dibutuhkan suatu perjanjian. Perihal perjanjian penyerahan jaminan oleh pihak debitur, maka terdapat perjanjian tambahan yang selalu mengikuti perjanjian pokok. ${ }^{3}$ Jaminan dapat dikatakan sebagai sesuatu hal yang berhubungan dengan bank dalam pelaksanaan penyerahan kredit. Bank sebagai kreditur melaksanakan langkah untuk memperoleh suatu kepastian dan untuk menjaga keamanan terhadap hal tersebut, mengharuskan kepada debitur menyerahkan barang untuk dijadikan jaminan dalam penyerahan kredit sesuai termuat pada Pasal 1131 dan Pasal 1132 Kitab Undang-Undang Hukum Perdata (selanjutnya disebut KUHPerdata). Seringkali digunakan hak kebendaan sebagai jaminan sebab memberikan hak kepada kreditur untuk dinilai dari segi ekonomi dan hukum sebelum diterima sebagai obyek jaminan. Salah satu contoh dari hak kebendaan ialah tanah ataupun tanah berikut bangunan dijadikan suatu jaminan yang dipasangkannya hak tanggungan. ${ }^{4}$

\footnotetext{
${ }^{1}$ Abdullah, N. (2017). Kedudukan Dan Kewenangan Notaris Dalam Membuat Akta Otentik. Jurnal Akta, 4(4), 655-664. DOI: http://dx.doi.org/10.30659/akta.v4i4.2508

${ }^{2}$ Adjie, Habib \& Sjaifurachman. (2011). Aspek Pertanggungajawaban Notaris dalam Pembuatan Akta. Bandung: Mandar Maju. h. 116.

${ }^{3}$ Wastu, I. B. G. G., Wairocana, I. G. N., \& Dewi Kasih, D. P. (2017). Kekuatan Hukum Perjanjian Kredit di Bawah Tangan pada Bank Perkreditan Rakyat. Acta Comitas, 2(1), 83-98.

${ }^{4}$ Kamelia, M. (2017). Peran Notaris Dalam Pembuatan Akta Perjanjian Kredit Dalam Perspektif Hukum Positif dan Hukum Islam. Jurnal Akta. 4(4), 575-584.
} 
Berdasarkan Pasal 51 Undang-Undang Nomor 5 Tahun 1960 tentang Peraturan Dasar Pokok-Pokok Agraria (selanjutnya disebut UUPA) menyatakan "hak tanggungan yang dapat dibebankan pada hak milik, hak guna-usaha dan hak guna-bangunan tersebut dalam pasal 25, 33, dan 39 diatur dengan undang-undang." Merujuk dari UUPA, maka terbitlah Undang-Undang Nomor 4 Tahun 1996 tentang Hak Tanggungan Atas Tanah Beserta Benda-Benda Yang Berkaitan Dengan Tanah (selanjutnya disebut UUHT). Pemasangan hak tanggungan diawali dengan Surat Kuasa Membebankan Hak Tanggungan (selanjutnya disebut SKMHT) dan selanjutnya Akta Pemberian Hak Tanggungan (selanjutnya disebut APHT) tujuannya memberikan kepastian serta perlindungan untuk para pihak.

Notaris/Pejabat Pembuat Akta Tanah mempunyai wewenang yakni saat obyek jaminan dibebankan hak tanggungan dan saat proses pencoretan hak tanggungan. Sebagaimana Pasal 22 UUHT yang mengatur tentang pencoretan hak tanggungan atau roya. Terjadinya proses roya tersebut dikarenakan telah lunasnya utang debitur. Proses roya dilakukan dengan melakukan pencoretan pada buku daftar tanah serta pada sertifikat yang semuanya dilaksanakan di Kantor Pertanahan. Untuk melakukan roya pada dasarnya diawali dengan pihak yang berkepentingan mengajukan permohonan ke Kantor Pertanahan yang membutuhkan waktu 7 (tujuh) hari sejak pengajuan tersebut diajukan.

Berdasarkan ketentuan dalam UUHT, sebagai debitur wajib untuk meroya sertifikat hak tanggungan sebagaimana yang tertulis pada sertifikat. Namun akan terdapat perbedaan apabila sertifikat hak tanggungan yang dipegang oleh kreditur hilang yang dikarenakan oleh kelalaian dari kreditur. Untuk hal seperti ini dalam melakukan proses roya terdahadap sertifikat tersebut diperlukan suatu akta khusus yang tujuannya menunjang para pihak yang ada didalamnya dapat melakukan proses roya. Yang dimaksud akta khusus dalam hal ini adalah akta konsen roya. Di dalam akta tersebut terdapat pernyataan dari kreditur bahwa sertifikat yang berada dalam kekuasaanya telah hilang. Seperti yang telah diketahui bahwa untuk melakukan proses roya diperlukan sertifikat hak tanggungan. Dalam hak tanggungan keberadaan akta konsen roya belum secara tegas diatur pada UUHT ataupun peraturan perundangundangan lainnya. Maka, mengakibatkan persoalan atas kedudukan hukum akta yang dibuat oleh notaris.

Meskipun secara khusus belum diatur dalam UUJN/P, UUHT atapun peraturan perundang-undangan lainnya, notaris tetap memiliki wewenang dalam membuat akta konsen roya sebagaimana ketentuan Pasal 15 UUJN/P. Akta konsen roya dibuat oleh seorang notaris yang merupakan kehendak atau inisiatif dari pihak itu sendiri serta perlu diketahui bahwa akta konsen roya ialah akta pihak, yang mana para pihak datang dihadapan notaris dengan memberikan keterangan dihadapan notaris dan dari keterangan tersebut notaris mengkonstatir untuk dituangkan dalam akta konsen roya. ${ }^{5}$

Dapat dikatakan bahwa suatu akta mempunyai kekuatan pembuktian apabila akta tersebut telah memenuhi ketiga kekuatan pembuktian, yakni kekuatan pembuktian lahir, formil, dan materil. Selain itu, yang tidak kalah pentingnya memenuhi persyaratan yang tercantum dalam UUJN/P, dengan terpenuhinya semua persyaratan

${ }^{5}$ Adjie, Habib \& Sjaifurachman. Op.cit. h. 46. 
tersebut maka akta tersebut baru dapat dikatakan mempunyai kekuatan yang sempurna. Jikalau tidak terpenuhinya salah satu syarat di atas, akta tidak menjadi alat bukti yang sempurna dan mengikat dan dapat berakibat kehilangan ke-autentikannya.

Berdasarkan uraian di atas, maka dirasa perlu dilakukan kajian secara hukum mengenai kapasitas seorang notaris dalam akta konsen roya dan kekuatan yuridis mengenai akta konsen roya sebagai syarat pencoretan hak tanggungan. Maka hal tersebut sangat menarik untuk dijadikan karya ilmiah berupa jurnal hukum yang berjudul "Kekuatan Yuridis Akta Konsen Roya yang Dibuat Oleh Notaris Sebagai Syarat Pencoretan Hak Tanggungan".

Bertolak dari judul di atas, maka dapat dirumuskan 2 rumusan masalah sebagai berikut: (1) bagaimana kapasitas akta konsen roya yang dibuat oleh notaris sebagai syarat pencoretan hak tanggungan?; dan (2) bagaimana kekuatan yuridis akta konsen roya yang dibuat oleh notaris sebagai syarat pencoretan hak tanggungan? Adapun tujuan dari penulisan karya ilmiah ini, yaitu: (1) untuk mengetahui dan menganalisis tentang kapasitas akta konsen roya yang dibuat oleh notaris sebagai syarat pencoretan hak tanggungan; dan (2) untuk mengetahui dan menganalisis tentang kekuatan yuridis akta konsen roya yang dibuat oleh notaris sebagai syarat pencoretan hak tanggungan.

Berkaitan dengan state of the art, maka dalam penulisan karya ilmiah ini turut membuat artikel-artikel ilmiah yang ter-publish yang memiliki kemiripan dalam hal topik yang tengah diteliti. Artikel-artikel sebagaimana dimaksud, antara lain:

1) Jurnal yang ditulis oleh Efty Hindaru Sudibyo dan Amin Purnawan, yang diterbitkan oleh Program Magister Kenotariatan Fakultas Hukum UNISSULA. Berjudul "Peran Notaris Dalam Pembuatan Akta Izin Roya Hak Tanggungan Karena Hapusnya Hutang Dalam Perspektif Kepastian Hukum". Permasalahan hukum yang dikaji, yaitu: (1) mengenai proses pembuatan akta izin roya hak tanggungan karena hapusnya utang; dan (2) peran notaris dalam pembuatan akta izin roya hak tanggungan karena hapusnya hutang dalam perspektif kepastian hukum. ${ }^{6}$

2) Jurnal yang ditulis oleh Graciela Georgina Afriani, yang diterbitkan oleh Fakultas Hukum Unsrat. Berjudul "Kedudukan Akta Izin Roya Hak Tanggungan Sebagai Pengganti Sertifikat Hak Tanggungan Yang Hilang Dalam Pemberian Kredit Bank". Permasalahan hukum yang dikaji, yaitu: (1) mengenai fungsi jaminan kredit dalam pemberian kredit oleh bank melalui hak tanggunga; dan (2) mengenai kedudukan akta izin roya dalam pemberian kredit bank. ${ }^{7}$

Memperhatikan materi muatan yang ada di dalam artikel ilmiah yang telah disebutkan di atas, maka dapat dipastikan bahwa karya ilmiah ini memiliki unsur pembaharuan

\footnotetext{
${ }^{6}$ Sudibyo, E. H., \& Purnawan, A. (2017). Peran Notariis Dalam Pembuatan Akta Izin Roya Hak Tanggungan Karena Hapusnya Hutang Dalam Perspektif Kepastian Hukum. Jurnal Akta, 4(2), 183-196.

${ }^{7}$ Afriani, G. G. (2019). Kedudukan Akta Izin Roya Hak Tanggungan Sebagai Pengganti Sertifikat Hak Tanggungan Yang Hilang Dalam Pemberian Kredit Bank. Lex Privatum, 6(9), h. 158.
} 
di dalamnya, baik ditinjau dari segi judul maupun rumusan masalah yang tengah dikaji.

\section{Metode Penelitian}

Karya ilmiah ini tergolong jenis penelitian normatif yang di dalamnya menggunakan 2 (dua) jenis pendekatan, yakni pendekatan perundang-undangan dan pendekatan konseptual. Adapun alasan memilih jenis penelitian hukum normatif ialah pada dasarnya dilakukan dengan melakukan analisa suatu peraturan dengan peraturan lainnya yang dilakukan secara regular atau terstuktur. ${ }^{8}$ Apabila dikaitkan dengan suatu penelitian hukum normatif, pada tulisan ini didasarkan dari adanya norma kabur, sebagaimana Pasal 15 ayat (1) UUJN/P hanya terdapat pengaturan tentang wewenangan notaris untuk membuat akta, tidak disebutkan wewenangan notaris untuk membuat akta konsen roya. Selain itu, berdasarkan ketentuan pada UUHT tidak mengatur secara khusus tentang akta konsen roya dalam hal hak tanggungan. Seluruh bahan hukum dalam karya ilmiah ini diperoleh melalui teknik studi dokumen dan selanjutnya dianalisis secara kualitatif.

\section{Hasil dan Pembahasan}

\subsection{Kapasitas Akta Konsen Roya Yang Dibuat Oleh Notaris Sebagai Syarat Pencoretan Hak Tanggungan}

Notaris memiliki wewenang untuk melakukan sebagian pekerjaan dari pemerintah khususnya pada bidang perdata, salah satunya membuat akta autentik yang memiliki kekuatan pembuktian yang sempurna, serta bersifat mengikat. Utamanya kata "mengikat" yang mempunyai arti selama dapat dibuktikan sesuatu yang ditulis didalamnya harus dianggap sebagai sesuatu yang benar. Akta autentiknya umumnya dibuat oleh seorang pejabat umum, yang dimaksud disini yakni notaris serta bentuk akta tersebut ditentukan oleh aturan yang berlaku. Kedudukan seorang notaris dalam hal membuat akta telah memenuhi unsur-unsur sesuai ketentuan Pasal 1868 KUHPerdata:

a. Pembuatan akta diharuskan dibuat dihadapan seorang pejabat umum; Sebagaimana diketahui notaris ialah pejabat umum yang memperoleh wewenang mengenai pembuatan akta autentik. Notaris bersifat independent tidak berpihak dengan siapapun namun pemerintah mempunyai wewenang dalam hal pengangkatan dan pemberhentian. Sehingga, kedudukan setiap akta yang dibuat dihadapan notaris telah memenuhi unsur ini.

b. Pembuatan bentuk akta harus sesuai peraturan perundang-undangan;

Sesuai Pasal 38 UUJN/P akta notaris diatur bentuknya dimulai dari bagianbagian akta sampai dengan apa saja yang harus tertuang dalam setiap bagiannya tersebut. Sehingga, dalam kedudukannya setiap akta yang dibuat sesuai dengan UUJN/P telah memenuhi unsur ini.

\footnotetext{
${ }^{8}$ Efendi, Jonaedi \& Johny Ibrahim. (2016). Metode Penelitian Hukum Normatif dan Empiris. Depok: Prenadamedia Group. h. 124.
} 
c. Pejabat umum yang bersangkutan harus mempunyai wewenang dalam pembuatan akta;

Sebagaimana ketentuan Pasal 15 UUJN/P notaris diberikan wewenang dalam menyelenggarakan pembuatan akta autentik. Akan tetapi, tetap patut memperhatikan kewenangan notaris mengenai akta yang dibuat. Sehingga, dalam kedudukannya apabila telah memperhatikan kewenangannya dalam pembuatan tiap akta tersebut maka telah memenuhi unsur ini. ${ }^{9}$

Terpenuhinya 3 (tiga) unsur di atas maka barulah akta memperoleh sifat autentiknya. Maka dapat dikatakan bahwa tidak selamanya akta memiliki sifat autentik meskipun dibuat oleh atau dihadapan notaris. Apabila salah satu syarat di atas tidak terpenuhi maka akta kehilangan sifat ke-autentikannya serta kekuatan akta tersebut sama dengan akta di bawah tangan.

Adanya penggolongan akta, yang mana akta dibagi menjadi 2 (dua) golongan ialah akta relaas dan akta partij. Mengenai akta relaas atau akta pejabat ialah notaris membuat akta sesuai permintaan para pihak. Notaris hanya menjabarkan suatu keadaan dalam hal ini dilihat, disaksikan serta dialami oleh notaris tersebut dalam jabatannya. Contoh dari akta relaas dalam hal membuat risalah RUPS dari sebuah PT. Penandatanganan pada akta relaas bukan merupakan suatu keharusan yang mempunyai maksud bahwa pihak yang hadir pada rapat tersebut tidak selamanya membubuhkan tanda tangannya dalam akta relaas dan hal tersebut tidak mempengaruhi keautentikan suatu akta relaas. Sedangkan, mengenai akta partij memuat uraian dari keterangan para pihak yang menghadap ke notaris. Penandatangan pada akta partij mengharuskan adanya tanda tangan seluruh pihak antara lain, kedua belah pihak, saksi-saksi dan notaris itu sendiri. ${ }^{10}$

Akta konsen roya termasuk dalam jenis akta partij. Hal tersebut disebabkan pemberi dan pemegang hak tanggungan menginginkan adanya suatu akta yang menyatakan bahwa utang debitur kepada pemegangan hak tanggungan telah lunas, akan tetapi sertifikat hak tanggungan yang bersangkutan hilang. Akta konsen roya dibuat dengan akta notariil dan harus ditandatangani oleh pihak yang berkepentingan, yaitu pemberi dan pemegangan hak tanggungan. Meskipun APHT merupakan akta PPAT yang menjadi dasar dalam pembuatan sertifikat hak tanggungan, namun akta konsen roya tetap menjadi kewenangan notaris. Selama tidak ditugaskan kepada pejabat umum lain, seorang notaris bewenangan membuat akta konsen roya, hal tersebut termasuk dalam akta para pihak untuk dibuatkan secara autentik serta merupakan kewenangannya.

Selain hal tersebut di atas, kewenangan notaris dalam membuat akta konsen roya dapat dihubungkan dengan sifat aktanya. Bahwa akta notaris merupakan akta autentik selama akta tidak bertentangan dengan peraturan perundang-undangan. Dikarenakan

${ }^{9}$ Hamzah, O. (2020). Analisis Kedudukaan Akta Konsen Roya Sebagai Pengganti Sertipikat Hak Tanggungan Yang Hilang. Jurnal Hukum dan Kenotariatan, 4(1), 86-103. DOI: http://dx.doi.org/10.334744/hukeno.v4i1.6450

${ }^{10}$ Hably, R. U., \& Djajaputra, G. (2019). Kewenangan Notaris Dalam Hal Membuat Akta Partij (Contoh Kasus Putusan Mahkamah Agung Nomor: 1003 K/PID/2015). Jurnal Hukum Adigama, 2(2), 482-507. 
sifatnya yang autentik, masyarakat menggunakan jasa notaris untuk membuat akta serta hal-hal tertentu sesuai peraturan perundang-undangan. Dalam hal ini akta notaris dikatakan sebagai akta autentik sebab memenuhi seluruh unsur autentiknya suatu akta sebagaimana ketentuan Pasal 1868 KUHPerdata. Pada dasarnya, tidak terdapat larangan untuk akta konsen roya dibuat oleh notaris lain yang bukan merupakan notaris yang sama sebelumnya membuatkan APHT dalam jabatannya selaku PPAT. Salah satu kewenangan notaris, yakni membuat akta autentik untuk siapapun yang memintanya selama telah memenuhi ketentuan peraturan yang berlaku. Dasar hukum notaris membuat akta konsen roya adalah Pasal 15 UUJN/P yang menyatakan bahwa semua perbuatan, perjanjian, serta ketetapan notaris berwenang untuk menyatakannya sebagai akta autentik yang diharuskan oleh aturan hukum sejauh tidak dibebankan pada pejabat yang ditentukan oleh undang-undang.

Dalam kapasitasnya, akta konsen roya dibuat oleh notaris hanya sebagai pengganti sertifikat hak tanggungan yang telah dinyatakan hilang, yang berfungsi untuk memenuhi syarat pencoretan hak tanggungan. Akta konsen roya tidak dapat dikatakan sama dengan sertifikat hak tanggungan yang mempunyai kekuatan eksekutorial sebab tidak diatur dalam undang-undang atau aturan yang tegas. ${ }^{11}$ Pembuatan akta konsen roya bertujuan melaksanakan persyaratan guna melaksanakan administrasi pertanahan. Telah disampaikan di atas bahwa dasar hukum dalam pembuatannya terdapat pada Pasal 15 ayat (1) UUJN/P. Akan tetapi, tidak adanya penjelasan secara khusus tentang wewenang notaris untuk membuat akta konsen roya. Kewenangan dalam ketentuan pasal tersebut hanya menjelaskan secara implisit berdasarkan penafsiran gramatikal. Dengan mengacu pada ketentuan tersebut, jikalau pihak yang berkepentingan berkehendak maka notaris secara hukum berwenang pada akta konsen roya sebagai syarat pencoretan hak tanggungan dalam hal setifikat hak tanggungan dinyatakan hilang.

\subsection{Kekuatan Yuridis Akta Konsen Roya Yang Dibuat Oleh Notaris Sebagai Syarat Pencoretan Hak Tanggungan}

Notaris dalam dunia perbankan mempunyai peran yang sangat penting dalam hal ini setiap aktivitas pada lembaga perbankan memerlukan seorang notaris untuk menjadi rekanan yang membantu proses berjalannya lembaga perbankan tersebut. Salah satunya dalam hal proses kredit atau para pihak yang akan menjaminkan hak atas tanah berupa sertifikat. Sebagaimana dalam UUJN/P notaris diberikan wewenang untuk membuat akta autentik yang bertujuan untuk menjamin kepastian hukum. Tanggungjawab seorang notaris hanya mencakup secara materiil atas akta yang dibuatnya.

Istilah hak tanggungan pada UUPA memiliki arti hak atas tanah yang jaminan, yang lahir dari adanya suatu perjanjian. Sebagai proses pemberian hak tanggungan, sesuai peraturan perundang-undangan terlebih dahulu dibuatkan APHT oleh PPAT. Proses pendaftaran hak tanggungan akan dilakukan oleh bank melalui PPAT kemudian dilanjutkan ke Badan Pertanahan Nasional (selanjutnya disebut BPN) dengan terlebih

\footnotetext{
${ }^{11}$ Purnama, Y. B. (2018). Kewenangann Notaris dalam Membuaat Akta Roya Hak Tanggungan. Jurnal Pemikiran dan Pembaharuan Hukum Islam, 21(1), 85-100. DOI: https://doi.org/10.15642/alqanun.2018.21.1.85-100
} 
dahulu notaris membuat APHT.12 Perjanjian dalam APHT sifatnya perjanjian tambahan. Perjanjian tambahan akan hapus apabila perjanjian pokoknya dihapus.

Mensyaratkan dilakukan roya terhadap hak tanggungan tersebut bilamana utang tersebut telah dihapuskan dengan melakukan pembayaran lunas. Ketentuan untuk melakukan roya terdapat dalam Pasal 22 UUHT. Setelah lunasnya utang dari debitur tersebut, maka selanjutnya dilakukan pencoretan terhadap hak tanggungan dengan cara melakukan roya di BPN Kabupaten/Kota. Saat inilah sertifikat hak tanggungan dan surat keterangan lunas dibutuhkan. Apabila sertifikat hak tanggungan hilang sebelum dilakukan roya yang disebabkan karena kelalaian dari pihak kreditur, tercecer, pencurian, maupun rusak dikarenakan force majeur. ${ }^{13}$ Sertifikat tersebut tidak hanya hilang ketika berada pada kreditur, namun dapat terjadi ketika berada pada debitur setelah lunasnya utang, namun debitur tidak kunjung melakukan proses roya. Sertifikat hak tanggungan yang terdaftar di BPN menjadi bukti terdapatnya suatu perjanjian hak tanggungan. Akibat yang timbul jika sertifikat hak tanggungan hilang dapat mengakibatkan tidak jelasnya proses pengikatan serta para pihak kedudukannya setelah debitur melunasi utang. Hendaknya perlu dibuatkan akta konsen roya untuk memperjelas dengan memberikan keterangan tentang hilangnya sertifikat hak tanggungan, yang dibuat secara autentik. Selanjutnya akta diberikan BPN sebagai syarat melakukan proses roya.

Berdasarkan uraian di atas bahwa akta konsen roya termasuk pada golongan akta partij. Akta tersebut dibuat berdasarkan permintaan pihak yang berkepentingan dengan melampiri surat keterangan hilang dari kepolisian hal inilah yang menjadi dasar seorang notaris membuat akta konsen roya. Disini notaris memiliki peran untuk memenuhi fungsi formil yakni melengkapi suatu perbuatan hukum sebab dengan dibuatkan akta konsen roya tersebut dapat digunakan menjadi alternatif dari sertifikat hak tanggungan yang hilang.

Pada Pasal 122 ayat (1) huruf a Peraturan Menteri Agraria/Kepala Badan Pertanahan Nasional Nomor 3 Tahun 1997 tentang Ketentuan Pelaksanaan Peraturan Pemerintah Nomor 24 Tahun 1997 tentang Pendaftaran Tanah Menteri Negara Agraria/Kepala Badan Pertanahan Nasional, mengatur bahwa: "pernyataan dari kreditur apabila utang yang dijadikan jaminan tersebut sudah hapus atau sudah dibayar lunas, dapat diwujudkan dalam akta autentik atau dalam surat pernyataan dibawah tangan." Berdasarkan ketentuan pasal tersebut, kreditur dapat membuat suatu akta autentik yang memuat utang yang dijamin telah hapus atau dibayarkan lunas. Dengan adanya aturan tersebut, dibuatlah akta autentik oleh notaris berupa akta konsen roya berdasarkan surat kehilangan dari kepolisian serta pada akta tersebut menyatakan sertifikat hak tanggungan yang menjadi syarat melakukan roya telah hilang, sebagai gantinya digunakanlah akta konsen roya. Dengan demikian pembuatan akta konsen roya tetap menjadi solusi hilangnya sertifikat hak tanggungan. Akta konsen roya digunakan untuk melaksanakan tertib administrasi. Hal ini mempunyai keterkaitan dengan teori kepastian hukum guna memperoleh kepastian terdapat beberapa perbuatan hukum berupa prosedur yang mewajibkan dilakukan meliputi membuat akta konsen roya dalam rangka untuk terpenuhinya proses roya di BPN serta

12Sudibyo, E. H., \& Purnawan, A., op.cit, 190.

${ }^{13}$ Afriani, G. G., op.cit, 158. 
bertujuan menjadikan sebagai alat pembuktian yang konkrit bahwa utang sudah dibayar penuh oleh debitur dan telah dihapuskan.

\section{Kesimpulan}

Akta konsen roya merupakan akta notariil yang memiliki kapasitas sebagai pengganti sertifikat hak tanggungan yang telah dinyatakan hilang, yang dapat digunakan untuk memenuhi persyaratan untuk melakukan pencoretan hak tanggungan. Akta konsen roya tidak dapat dikatakan sama dengan sertifikat hak tanggungan yang mempunyai kekuatan eksekutorial. Adapun mengenai kekuatan yuridis pada akta konsen roya dapat dilihat dari perspektif kepastian hukum yang mana notaris berperan dalam pembuatan akta tersebut guna memenuhi proses pencoretan hak tanggungan di Kantor Pertanahan Nasional dan dapat dijadikan sebagai alat pembuktian yang konkrit bahwa utang sudah lunas dan telah dihapuskan.

\section{Daftar Pustaka/Daftar Referensi}

\section{$\underline{\text { Buku }}$}

Adjie, Habib \& Sjaifurachman. (2011). Aspek Pertanggungajawaban Notaris dalam Pembuatan Akta. Bandung: Mandar Maju.

Efendi, Jonaedi \& Johny Ibrahim. (2016). Metode Penelitian Hukum Normatif dan Empiris. Depok: Prenadamedia Group.

\section{Jurnal}

Abdullah, N. (2017). Kedudukan Dan Kewenangan Notaris Dalam Membuat Akta Otentik. Jurnal Akta, 4(4), 655-664. DOI: http:/ / dx.doi.org/10.30659/akta.v4i4.2508

Afriani, G. G. (2019). Kedudukan Akta Izin Roya Hak Tanggungan Sebagai Pengganti Sertifikat Hak Tanggungan Yang Hilang Dalam Pemberian Kredit Bank. Lex Privatum, 6(9).

Hably, R. U., \& Djajaputra, G. (2019). Kewenangan Notaris Dalam Hal Membuat Akta Partij (Contoh Kasus Putusan Mahkamah Agung Nomor: 1003 K/PID/2015). Jurnal Hukum Adigama, 2(2), 482-507.

Hamzah, O. (2020). Analisis Kedudukan Akta Konsen Roya Sebagai Pengganti Sertipikat Hak Tanggungan Yang Hilang. Jurnal Hukum dan Kenotariatan, 4(1), 86103. DOI: http://dx.doi.org/10.33474/hukeno.v4i1.6450

Kamelia, M. (2017). Peran Notaris Dalam Pembuatan Akta Perjanjian Kredit Dalam Perspektif Hukum Positif dan Hukum Islam. Jurnal Akta. 4 (4). 
Purnama, Y. B. (2018). Kewenangan Notaris dalam Membuat Akta Roya Hak Tanggungan. Jurnal Pemikiran dan Pembaharuan Hukum Islam, 21(1), 85-100. DOI: https:/ / doi.org/10.15642/alqanun.2018.21.1.85-100

Sudibyo, E. H., \& Purnawan, A. (2017). Peran Notaris Dalam Pembuatan Akta Izin Roya Hak Tanggungan Karena Hapusnya Hutang Dalam Perspektif Kepastian Hukum. Jurnal Akta, 4(2).

Wastu, I. B. G. G., Wairocana, I. G. N., \& Dewi Kasih, D. P. (2017). Kekuatan Hukum Perjanjian Kredit di Bawah Tangan pada Bank Perkreditan Rakyat. Acta Comitas, 2(1).

\section{Peraturan Perundang-Undangan}

Kitab Undang-Undang Hukum Perdata.

Undang-Undang Nomor 5 Tahun 1960 tentang Peraturan Dasar Pokok-Pokok Agraria (Lembaran Negara Tahun 1960 Nomor 104 Tambahan lembaran Negara Nomor 2043).

Undang-Undang Nomor 4 Tahun 1996 tentang Hak Tanggungan Atas Tanah Beserta Benda-Benda Yang Berkaitan Dengan Tanah (Lembaran Negara Republik Indonesia Tahun 1996 Nomor 42, Tambahan Lembaran Negara Republik Indonesia Nomor 3632).

Undang-Undang Nomor 2 Tahun 2014 tentang Perubahan Atas Undang-Undang Nomor 30 Tahun 2004 tentang Jabatan Notaris (Lembaran Negara Republik Indonesia Tahun 2014 Nomor 3 Tambahan Lembaran Negara Republik Indonesia Nomor 5491).

Peraturan Menteri Agraria/Kepala Badan Pertanahan Nasional Nomor 3 Tahun 1997 tentang Ketentuan Pelaksanaan Peraturan Pemerintah Nomor 24 Tahun 1997 tentang Pendaftaran Tanah Menteri Negara Agraria/Kepala Badan Pertanahan Nasional. 